\title{
Analisis Penanganan Penumpang Disabilitas Pada Maskapai Citilink di Bandar Udara Internasional Adisutjipto Yogyakarta
}

\author{
Yuliantoharinugroho \\ Akademi Manajemen Administrasi Yogyakarta \\ email : yulianto@amayogyakarta.ac.id
}

\begin{abstract}
Abstrak
Penelitian ini merupakan penelitian kualitatif deskriptif. Subyek penelitian ini adalah staf Maskapai Citilink Indonesia di Bandara Adisujipto Yogyakarta. Metode pengumpulan data yang digunakan adalah observasi, wawancara, dokumentasi dan studi pustaka. Penelitian ini bertujuan untuk mengetahui penanganan penumpang disabilitas pada Maskapai Citilink di Bandara Adisutjipto Yogyakarta, cara Maskapai Citilink mengatasi permasalahan dalam penanganan penumpang disabilitas di Bandara Adisutjipto Yogyakarta.

Hasil penelitian menunjukkan cara penanganan penumpang disabilitas pada Maskapai Citilink di Bandar Udara Internasional Adisujipto Yogyakarta yaitu Petugas check-in akan memeriksa setiap identitas penumpang untuk mengetahui kondisi setiap penumpang. Pada saat check-in setiap penumpang disabilitas wajib melapor agar penumpang dengan Tunanetra, Tunarungu, Autis dan penumpnag yang membutuhkan kursi roda seperti halnya yang penumpang ingin didampingi sampai naik pesawat maka petugas akan memberikan sesuai dengan kebutuhan penumpang disabilitas. Permasalahan yang sering muncul adalah penumpang disabilitas yang tidak melapor ke Counter Check in, sehingga petugas pasasi akan menaikkan penumpang disabilitas yang mestinya masuk lebih awal, dimasukkan setelah penumpang yang lain memasuki pesawat.
\end{abstract}

\section{Kata Kunci : Penanganan, Penumpang, Disabilitas}

\begin{abstract}
This research is a descritive qualitatif research. The subject of this research is Citilink Indonesia Airline staff at Yogyakarta Adisutjipto Airport. Data collection methods used are observation, interviews, documentation and literature study. This study aims to determine the handling of disabled passengers on Citilink Airlines at Yogyakarta Adisutjipto Airport, how Citilink Airlines overcomes problems in handling disabled passengers at Yogyakarta Adisutjipto Airport.

The results of the study show how to handle disabled passengers on Citilink Airlines at Yogyakarta Adisutjipto International Airport, namely the Check-in officer will check each passenger's identity to determine the condition of each passenger.At check-in, every passengers with visual impairments, autism and passengers who need a wheelchair aswell as those who want to be accompanied by passengers to board the plane, the officer will provide according to the needs of passengers with disabilities. The problem that often arises is passengers with disabilities who do not report to the Check-in Counter, so that the passage officer will pick up disabled passengers who should have entered earlier, entered after the other passengers have entered the plane.
\end{abstract}

Keyword : handling, passenger, disability 


\section{PENDAHULUAN}

Pada saat ini tantangan dalam bisnis jasa operasional penerbangan semakin besar banyak perusahaan berlomba-lomba untuk meningkatkan kualitas pelayanannya dan memperbanyak pilihan layanan jasa perusahaan agar mereka dapat menciptakan dan mempertahankan pelanggan yang puas dan loyal. Pelayanan yang diberikan oleh perusahaan kepada pelanggannya dapat berpengaruh jika pelanggan merasa puas akan pelayanan yang diberikan dan memberikan manfaat untuk perusahaan yaitu mengungkapkan kepuasannya kepada orang lain, sehingga semakin banyak masyarakat yang ingin menggunakan pelayanan dari perusahaan tersebut.Namun, jika pelayanan yang diberikan dirasa buruk oleh pelanggan maka ini juga dapat mengakibatkan kerugian bagi perusahaan yaitu menurunnya minat masyarakat untuk menggunakan pelayanan perusahaan, berkurangnya kepercayaan masyarakat akan pelayanan perusahaan dan tentu bisnis perusahaanpun akan menurun. Oleh sebab itu, pada sebuah organisasi atau perusahaan, salah satu cara yang digunakan untuk meningkatkan pelayanan kepada pelanggannya yaitu dengan membangun dan menjaga komunikasi yang baik dengan pelanggan.

Kualitas pelayanan ini menjadi penting karena akan berdampak langsung pada citra perusahaan maskapai. Kualitas pelayanan yang baik akan menjadi sebuah keuntungan bagi perusahaan maskapai. Bagaimana tidak, jika suatu perusahaan sudah mendapat nilai positif di mata konsumen, maka konsumen tersebut akan memberikan feedback yang baik, serta bukan tidak mungkin akan menjadi pelanggan tetap. Maka dari itu, sangat penting untuk mempertimbangkan aspek kepuasan pelanggan terkait kualitas pelayanan yang diberikan. Jenisjenis pelayanan yang dapat diberikan misalnya berupa kemudahan, kecepatan, kemampuan, dan keramahtamahan yang ditunjukkan melalui sikap dan tindakan langsung kepada konsumen.

Kualitas pelayanan menurut J.Supranto (2006:226) adalah sebuah hasil yang harus dicapai dan dilakukan dengan sebuah tindakan. Namun tindakan tersebut tidak berwujud dan mudah hilang, tetapi dapat dirasakan dan diingat. Dampaknya adalah konsumen dapat lebih aktif dalam proses mengkonsumsi produk dan jasa suatu perusahaan.

Dalam hal pelayanan ini siapapun berhak untuk mendapatkan pelayanan baik passenger handling dan penumpang disabibilitas. Tetapi terkadang timbul kekhawatiran tersendiri bagi penyandang disabilitas ketika akan melakukan perjalanan. Ketakutan yang sering timbul antara lain takut akan merepotkan orang lain selama perjalanan. Selain itu, keterbatasan fasilitas penunjang terkadang menjadi alasan bagi penyandang disabilitas untuk takut melakukan perjalanan. Dengan ditingkatkannya pelayanan maskapai untuk penumpang berkebutuhan khusus maka penyandang disabilitas dapat bepergian dengan lebih mudah dan nyaman.

UU No. 1 Tahun 2009 Tentang Penerbangan Pasal 123. Telah menegasakan secara detail bagaimana prosedur perlakuan khusus kepada penyandang disabilitas dalam pasal 134 yang merinci peraturan pengangkutan untuk penyandang cacat, lanjut usia,anak-anak dan orang sakit. Isi UU No.1 Tahun 2009 tentang penerbangan pasal 134 adalah sebagai berikut:

1. Penyandang cacat, lanjut usia, anak-anak, dibawah usia 12(dua belas) tahun dan orang sakit berhak memperoleh pelayanan berupa perlakuan dan fasilitas khusus dari badan usaha angkutan udara niaga

2. Layanan terdiri atas persetujuan dan fasilitas khusus yang disetujui pada ayat (1) sebuah

a) Pemberian prioritas tambahan tempat duduk

b) Penyediaan fasilitas kemudahan untuk naik ke dan turun dari pesawat udara

c) Penyediaan fasilitas untuk penyandang cacat selama berada di pesawat udara

d) Sarana bantu bagi orang sakit

e) Tersedia personel yang dapat berkomunikasi dengan penyandang cacat ,lanjut usia, anakanak, orang sakit 
f) Tersedianya buku petunjuk tentang keselamatan dan keamanan penerbangan bagi penumpang pesawat udara dan sarana lain yang dapat dimengerti oleh penyandang disabilitas, lanjut usia, dan orang sakit.

g) Pemberian perlakuan dan fasilitas khusus sebagaimana dimaksud pada ayat (2) tidak dipungut biaya tambahan.

Maskapai Citilink Indonesia berkomitmen untuk terus mengembangakan berbagai layanan dan program yang mampu meningkatkan kenyamanan dan kemudahan khususnya penumpang disabilitas.

\section{Perumusan Masalah}

Permasalahan pada penelitian ini adalah bagaimana penanganan penumpang disabilitas pada Maskapai Citilink di Bandara Adisutjipto Yogyakarta.

Tujuan Penelitian

Tujuan penelitian ini adalah :

1. Untuk mengetahui penanganan penumpang disabilitas pada Maskapai Ctilink di Bandara Adisutjipto Yogyakarta.

2. Untuk mengetahui kendala-kendala yang dihadapi Maskapai Citilink dalam melayani penumpang disabilitas di Bandara Adisutjipto Yogyakarta dan cara mengatasi kendalakendala dalam pelayanan penumpang disabilitas di Bandara Adisutjipto Yogyakarta.

\section{TINJAUAN PUSTAKA}

1. Pengertian penanganan penumpang (Passenger Handling)

Damardjati dalam bukunya istilah-istilah Dunia Pariwisata (2001 : 94) " Passenger adalah setiap orang yang diangkut maupun yang harus diangkut di dalam pesawat udara ataupun badan yang meyelanggarakan angkutan tersebut "

Kata Passenger berasal dari Bahasa Inggris. Arti Pasengger menurut Echols (2003:228) dalam kamus Inggris Indonesia Passanger adalah penumpang. Sedangkan menurut Ali (2000:325) "Handling adalah penanganan". Menurut kamus Bahasa Indonesia (2001:1137) "penanganan adalah proses,cara,pembuatan menangani”.

Menurut Suwarno (2001:1) "Passenger Handling adalah penanganan atau pelayanan penumpang". Dimana menurutnya rangkaian tata laksana penanganan atau pelayanan penumpang dapat diuraikan berdasarkan urutan sebagai berikut :

a. Resevation yaitu proses pemesanan tempat

b. Fare calculation adalah sistem perhitungan tarif

c. Ticketing yaitu proses pembuatan dan penjualan ticket

d. Departure yaitu proses pelayanan keberangkatan penumpang di bandar udara

e. Inflight service yaitu proses pelayanan penumpang slama di perjalanan/didalam pesawat

f. Transit / transfer yaitu proses pelayanan penumpang di kota persinggahan

g. Arrival yaitu proses penanganan penumpang di bandar udara kota tujuan.

2. Macam - macam penumpang disabilitas

Menurut Undang-Undang Nomor 4 Tahun 1997 tentang Penyandang Cacat, Penyandang Disabilitas dikategorikan menjadi tiga jenis, yaitu sebagai berikut:

a. Cacat Fisik

Cacat fisik adalah kecacatan yang mengakibatkan gangguan pada fungsi tubuh, antara lain gerak tubuh, penglihatan, pendengaran, dan kemampuan berbicara. Cacat tubuh atau tuna daksa berasal dari kata tuna yang berarati rugi atau kurang, sedangkan daksa berarti tubuh. Jadi tuna daksa ditujukan bagi mereka yang memiliki anggotatubuh tidak sempurna. 
Cacat tubuh dapat digolongkan sebagai berikut:

1) Menurut sebab cacat adalah cacat sejak lahir, disebabkan oleh penyakit, disebabkan kecelakaan, dan disebabkan oleh perang.

2) Menurut jenis cacatnya adalah putus (amputasi) tungkai dan lengan; cacat tulang, sendi, dan otot pada tungkai dan lengan; cacat tulang punggung.

b. Cacat Mental

Cacat mental adalah kelainan mental dan atau tingkah laku, baik cacat bawaan maupun akibat dari penyakit,.

c. Cacat Ganda atau Cacat Fisik dan Mental

Yaitu keadaan seseorang yang menyandang dua jenis kecacatan sekaligus. Apabila yang cacat adalah keduanya maka akan sangat mengganggu penyandang cacatnya.

Dari uraian diatas penulis bermaksud untuk menghindari pejelasan yang lebih luassehingga penulis mengambil macam-macam penumpang disabilitas sebagai berikut :

1) Penumpang yang menggunakan kursi roda

2) Tunanetra

3) Tunarunu

4) Autis

3. Pengertian Bandar Udara

Bandar udara adalah kawasan didarat atau perairan dengan batas-batas tertentu yang digunakan sebagai tempat pesawat udara mendarat dan lepas landas, naik turun penumpang,bongkar muat barang,dan tempat perpindahan intra dan antarmoda transportasi, yang dilengkapi dengan fasilitas keselamatan dan keamanan penerbangan, serta fasilitas pokok dan fasilitas lainnya. Menurut Annex 14 dari ICAO (International Civil Aviation Organization) Bandar udara adalah area tertentu di daratan atau perairan (termasuk bangunan, instalasi dan peralatan) yang diperuntukkan baik secara keseluruhan atau sebagian untuk kedatangan, keberangkatan, dan pergerakan pesawat. Menurut PT (persero) Angkasa Pura Bandar Udara adalah lapangan udara, termasuk segala bangunan dan peralatan yang merupakan kelengkapan minimal untuk menjamin tersedianya fasilitas bagi angkutan udara masyarakat .

\section{METODE PENELITIAN}

1. Tempat Penelitian

Penelitian ini dilaksanakan di Bandar Udara Internasional Adisujipto, J1. Raya Solo KM.9, Maguwoharjo, Kec. Depok, Kab Sleman, Daerah Istimewa Yogyakarta 55282

2. Obyek Penelitian

Obyek dalam penelitian ini adalah penanganan Penumpang disabilitas di Maskapai Citilink di Bandara Internasional Adisutjipto Yogyakarta

\section{Jenis Penelitian}

Penelitian ini adalah jenis penelitian kualitatif. Menurut Moleong (2006:247), metode kualitatif yaitu menyajikan data yang dimulai dengan menelaah seluruh data yang tersedia dari berbagai sumber data yang terkumpul, mempelajari data, menelaah menyusunnya dalam satusatuan, yang kemudian dikategorikan pada tahap berikutnya dan memeriksakan keabsahan data serta menafsirkannya dengan analisis sesuai dengan kemampuan daya nalar peneliti untuk membuat kesimpulan peneliti. 
4. Metode Pengumpulan Data

a. Observasi

Menurut Jaco (2010:112) observasi adalah bagian dalam pengumpulan data. Observasi berarti mengumpulkan data langsung dari lapangan. Data yang diobservasi dapat berupa gambaran tentang sikap, kelakuan, perilaku, tindakan, keseluruhan interaksi antar manusia. Data observasi juga dapat berupa interaksi dalam suatu organisasi atau pengalaman anggota dalam berorganisasi.

b. Wawancara

Menurut Rohidi (2011:208) dalam buku Julia (2018:49), wawancara adalah suatu teknik yang digunakan untuk memperoleh informasi tentang kejadian yang oleh peneliti tidak dapat diamati sendiri secara langsung.

c. Dokumentasi

Menurut Afifuddin dan Saebani dalam buku Sugiarto (2015:88), dokumentasi adalah teknik pengumpulan data dengan cara mencari bukti-bukti dari sumber nonmanusia terkait dengan objek yang diteliti. Menurut Sugiyono (2013:83) dalam buku Sugiarto (2015:88) dokumentasi berupa tulisan, gambar dan karya monumental dari seseorang.

d. Studi Pustaka

Menurut Sugiyono (2014:166) metode studi pustaka adalah suatu pembahasan yang berdasarkan pada buku-buku referensi yang bertujuan untuk memperkuat materi pembahasan maupun sebagai dasar untuk menggunakan rumus-rumus tertentu dalam menganalisa dan mendesain suatu struktur. Pada tahap ini penulis melakukan studi pustaka denganmengumpulkan beberapa data dari buku, Undang-Undang, Keputusan Menteri dan lain-lain yang berhubungan dengan masalah dan tujuan penelitian yang ada.

\section{Analisa Data}

Dalam penelitian ini peneliti menggunakan analisis data model interaktif. Menurut Miles dan Huberman (1984) dalam buku Hanifah (2014:76) mengemukakan bahwa aktifitas dalam analisis kualitatif dilakukan secara interaktif dan berlangsung secara terus menerus sampai tuntas, sehingga datanya sudah jenuh. Aktivitas dalam analisis data, yaitu : data reduction, data display dan data conclusion.

a. Data reduction (Reduksi data)

Mereduksi data berarti merangkum memilih hal-hal yang pokok, memfokuskan pada hal-hal yang penting, dicari tema dan polanya.

b. Data display (Penyajian data)

Setelah data reduksi, maka langkah selanjutnya adalah mendisplay data. Kalau dalam penelitian kuantitatif penyajian dapat berupa tabel, grafik, maka dalam penelitian kualitatif penyajian dilakukan dalam bentuk penelitian kualitatif penyajian dilakukan dalam bentuk uraian singkat.

c. Conslusion/verifacation

Kesimpulan dalam penelitian kualitatif mungkin akan menjawab rumusan masalah yang dirumuskan sejak awal. Jadi adapun metode analisis data yang digunakan mengikuti metode Miles dan Huberman antara lain :

1) Data dari hasil wawancara, observasi, dan lain-lain dibuat catatan lapangan secara lengkap.

2) Dari penelitian lapangan di buat reduksi data. Adapun reduksi datanya berupa pokokpokok yang penting.

3) Dari reduksi kemudian diikuti penyajian data yang berupa cerita sistematis dengan suntingan peneliti supaya maknannya lebih jelas. Sajian data ini dilengkapi faktor pendukung.

4) Berdasarkan sajian tersebut kemudian dirumuskan kesimpulan sementara. 


\section{HASIL DAN PEMBAHASAN}

1. Penanganan penumpang disabilitas pada maskapai Citilink di Bandar Udara International Adisujipto Yogyakarta.

UU No. Tahun 2009 Tentang Penerbangan Pasal 134 undang -undang nomor 1 tahun 2009 tentang penerbangan telah menengaskan secara detail bagaimana prosedur pelakuan khusus kepada penyandang disabilitas dalam pasasl 134 yang merinci peraturan pengakuan untuk penyandang cacat, lanjut usia, anak-anak, dan/atau oarang sakit. Isi UU No. 1 Tahun 2009 tentang penerbangan pasal 134 adalah sebagai berikut :

a. Penyandang cacat, lanjut usia, anak-anak dibawah usia 12 tahun atau orang sakit berhak memperoleh pelayanan berupa perlakuan dan fasilitas khusus dari badan usaha angkutan udara niaga.

b. Pelayanan berupa perlakuan dan fasilitas khusus sebagaimana dimaksud pada ayat (1) meliputi :

1) Pemberian prioritas tambahan tempat duduk;

2) Penyediaan fasilitas kemudahaan untuk naik ke dan turun dari pesawat udara

3) Penyadiaan fasilitas untuk penyandangcacat selama beradad di pesawat udara

4) Sarana bantu bagi orang sakit

5) Penyedian fasilitas untuk anak-anak selama beradad di pesawat udara

6) Tersediannya personal yang dapat berkomunikasi dengan penyandang cacat anjut usia, anak-anak, atau orang sakit dan

7) Tersedianya buku petunjuk tentang keselamatan dan keamanan penerbangan bagi penumpang pesawat udara dan sarana lain yang dapat dimengerti oleh penyandang cacat, lanjut usia, dan orang sakit.

c. Pemberian perlakuan dan fasilitas khusus sebagaimana dimaksud pada ayat (2) tidak dipunggut biaya tambahan.

Prosedur penanganan penumpang pesawat udara merupakan hal yang sangat penting yang perlu dilakukan saat hendak melakukan penerbangan. Hal pertama yang dilakukan oleh petugas check-in counter adalah memeriksa setiap identitas diri setiap penumpang.

Memeriksa kelengkapan dokumen merupakan salah satu tugas yang perlu dilakukan oleh petugas. Dimulai dengan tiket yang harus sama dengan identitas penumpang, petugas check-in conter juga harus menimbang setiap bagasi yang diawa oleh penumpang serta memberikan label pada setiap bagasi tersebut. Jika terjadi kelebihan muatan, maka selaku petugas check-in counter wajib untuk meminta pembayaran untuk excess baggage. Dan kemudian memberrikan bukti excess baggage pada penumpang.

Dalam setiap pelayanan terhadap penanganan penumpang,petugas check-in wajib menyapa setiap penumpang dengan senyum ramah. Penumpang akan menilai bagaimana petugas dari airlines tersebut melayaninya dan membuat penumpang untuk tertarik menggunakan jasa airlines tersebut.

Penumpang disabilitas yang dilayani pada maskapai Citilink di Bandara International Adisujipto yaitu penumpang yang menggunakan kursi roda, tunanetra, tunarungu dan autis. Data dalam penelitian ini diperoleh melalui observasi serta didukung dengan hasil wawancara yang peneliti lakukan dengan petugas staff Check-In Counter Maskapai Citilink yang menyebutkan bahwa dalam hal penanganan penumpang, tidak hanya melayani passenger handling tetapi juga special passenger. Untuk penanganan special passanger (penumpang disabilitas) harus benar-benar memberikan pelayanan yang baik kepada penumpang Maskapai Citilink dengan disabilitas, mulai dari check-in sampai masuk kedalam pesawat. Cara melayani dan menangani penumpang harus sesuai 
dengan Standar Operasional Prosedur (SOP) yang sudah ditentukan dalam perusahaan penerbangan.

Standar Operasional Prosedur (SOP) pelayanan penumpang disabilitas pada Maskapai Citilink di Bandara Internasional Adisutjipto adalah sebagai berikut :

a. Penumpang yang menggunakan kursi roda

Hal-hal yang perlu dilakukan untuk menangani penumpang disabilitas pada Maskapai Citilink di Bandara Internasional Adisutjipto yang memerlukan kursi roda adalah :

1) Petugas pasasi akan mengucapkan salam telebih dahulu,lalu meminta kode booking tiket beserta tanda pengenalnya

2) Pada saat check-in petugas pasasi akan bertanya kepada penumpang apakah ada riwayat sakit atau tidak, jika penumpang mengatakan ada dan penumpang tersebut juga menunjukkan surat dokter bahwa penumpang tersebut layak terbang, maka petugas pasasi akan mengisi surat peryataan yang di dalam surat peryataan tersebut yang meliputi nomor set,nama airlines, nomor penerbangan dan tujuan destinasi penumpang.

3) Petugas pasasi juga akan menawarkan kursi roda jika penumpang tersebut tidak dapat berjalan terlalu jauh karena faktor sakit, seperti yang dijelaskan pada poin 2, jika penumpang tersebut membutuhkannya maka salah satu petugas pasasi akan membantu penumpang tersebut dengan kursi roda dan akan dilayani mulai dari check-in sampai masuk ke ruang tunggu. Apabila penumpang sulit untuk mengendalikan kursi rodanya tawarkanlah bantuan tersebut ketika penumpang pergi sendiri tanpa ada pendampingnya.

4) Ketika sampai di tangga pesawat, apabila penumpang tidak dapat naik pesawat sendiri, maka petugas pasasi akan membantu memapah penumpang naik ke pesawat sampai ke kursi/ seat yang sudah ditentukan pada saat check-in.

5) Setelah sampai di dalam pesawat maka petugas pasasi akan saling serah terima pelayanan berkebutuhan khusus tersebut kepada awak kabin. Selama perjalanan, awak kabin akan memastikan keadaan penumpang tersebut dan memberikan pelayanan yang maksimal hingga sampai di tempat tujuan.

6) Pada saat pesawat sudah mendarat di tempat tujuan, penumpang berkebutuhan khusus masih tetap diberikan pelayanan maksimal mulai turun dari pesawat sampai keluar dari kawasan kedatangan. Penumpang ini juga masih akan diberikan fasilitas kursi roda untuk digunakan pada saat turun dari pesawat.

b. Penumpang Tunanetra

Hal-hal yang perlu dilakukan untuk menangani penumpang tunanetra pada Maskapai Citilink di Bandara Internasional Adisutjipto antar lain :

1) Pertugas akan memberikan salam terlebih dahulu, serta meminta kode booking dan identitas diri penumpang.

2) Jika penumpang tidak dibantu check-in oleh keluarga (berangkat sendiri), maka petugas akan mengambil tindakan dalam melayani penumpang khusus tunanetra ini. Jika penumpang tersebut hanya tunanetra saja tetapi masih dapat mendengarkan, maka petugas pasasi akan membantu penumpang tersebut dengan memberikan arahan menggunakan suara.

3) Penumpang tersebut akan dipandu dari counter check-in menuju ke ruang tunggu. Petugas pasasi akan melaporkan penumpang ini terlebih dahulu kepada petugas yang bertugas di boarding gate untuk dihandle pada saat boarding.

4) Petugas boarding akan mengantar penumpang tunanetra terlebih dahulu pada saat boarding. Agar tidak mengganggu penumpang lainnya yang akan boarding, ketika hendak berbicara, sapa penumpang atau sentuh tangan secara pelan. 
5) Pada saat petugas mengantarkan penumpang tunanetra, biarkan penumpang tersebut memegang tangan anda (staf).

6) Petugas akan berada di depan penumpang tersebut agar mereka dapat mengetahui arah jalan yang dilalui untuk naik ke pesawat tersebut dan petugas akan memberikan instruksi jika ada tangga untuk naik ke pesawat.

7) Setelah itu petugas boarding gate akan menempatkan penumpang tunanetra di seat yang dekat pintu darurat, agar nantinya tidak menghalangi tugas dari awak kabin. Pada saat sampai di tempat tujuan biasanya penumpang khusus seperti ini akan turun belakangan setelah semua penumpang turun dari pesawat dan tetap dipandu oleh petugas pasasi di tempat tujuan sampai penumpang tersebut bertemu dengan penjemput penumpang (keluarga).

c. Penumpang Tunarungu

Penanganan penumpang tunarungu pada Maskapai Citilink di Bandara Internasional Adisutjipto yaitu sebagai berikut :

1) Petugas pasasi akan memberikan salam dan meminta kode booking tiket serta identitas diri penumpang. Jika penumpang ini dicheck-inkan oleh keluarga atau penumpang yang bersangkutan bepergian sendiri, maka petugas pasasi akan bertanya kepada pihak keluarga, biasanya dengan berkata "mohon maaf pak, penumpang yang bersangkutan hanya memiliki keterbatasan pendengaran saja kan?

2) Petugas pasasi akan berkomunikasi dengan mereka melalui tulisan, misalnya memberi petunjuk ke boarding gate. Jangan menggunakan Bahasa isyarat atau gerakan isyarat tangan, atau bisa langsung diantarkan masuk ke dalam ruang tunggu hingga naik ke pesawat.

3) Penumpang ini harus duduk di tempat yang tidak menghalangi tugas awak pesawat, yaitu yang dapat menghalangi jalan ke area perlengkapan darurat ataupun mengganggu kecepatan proses evakuasi penumpang lain.

4) Mereka harus ditempatkan sedekat mungkin dengan pintu darurat.

d. Penumpang Autis

Untuk penanganan penumpang autis pada Maskapai Citilink di Bandara Internasional Adisutjipto harus ada pendamping yang bersamanya selama perjalanan baik dari keluarga atau orang yang dapat menenangkannya pada saat kambuh. Penerbangan mungkin dapat diterima untuk diberangkatkan bila :

1) Penumpang tersebut ditemani oleh penjaga yang secara fisik mampu mengatasi tindakan yang kurang baik selama penerbangan (jika bepergian sendiri).

2) Jika penumpang tersebut memerlukan pemberian obat penenang sebelum jadwal keberangkatan, maka penjaganya harus mampu menghitungkan durasi yang tepat hingga tiba di tempat tujuan.

3) Penumpang akan diberangkatkan ketika dalam keadaan tidak kambuh.

4) Mereka akan boarding lebih dahulu dan turun dari pesawat setelah penumpang yang lain turun.

5) Mereka tidak boleh duduk di pintu darurat, namun tetap dalam pengawasan awak pesawat.

Hal-hal yang perlu diperhatikan pada saat terbang bagi penyandang disabilitas seperti yang diuraikan diatas yaitu :

1) Tiba lebih awal

Karena penyandang disabilitas memerlukan berbagai prosedur tambahan yang mungkin memakan waktu, jadi disarankan datang ke bandara lebih awal dari 
jadwal penerbangan. Idealnya penumpang harus sudah berada di bandara 2-3 jam sebelum keberangkatan untuk menyelesaikan prosedur yang diperlukan.

2) Membawa dokumen medis

Dokumen medis ini dibutuhkan sebagai acuan penanganan pertama jika penumpang mengalami gangguan saat terbang. Selain itu, dokumen medis ini bisa membantu menunjukkan kodisi saat terbang, apakah memerlukan beberapa fasilitas tambahan seperti kursi roda, tandu dan sebagainya atau tidak. Dokumen ini juga dapat menunjukkan bahwa kondisi penumpang dalam keadaan sehat dan prima serta mampu terbang tanpa pengawalan khusus.

3) Bawa obat-obatan

Jika masih mengkonsumsi obat berdasarkan resep dari dokter, jangan lupa untuk membawa obat tersebut lengkap dengan resep resmi agar obat-obatan tersebut bisa diijinkan dibawa masuk ke dalam kabin saat melewati pemeriksaan bandara.

4) Beli asuransi perjalanan.

Pembelian asuransi dilakukan agar penumpang merasa aman saat melakukan perjalanan serta untuk mengantisipasi hal-hal yang tidak diinginkan.

2. Kendala - kendala dalam melayani penumpang disabilitas di Bandar Udara Internasional Adisutjipto Yogyakarta.

Apabila penumpang melakukan perjalanan sendiri tanpa ada kerabat atau saudara yang menemani, penumpang harus melapor ke counter check-in terutama apabila penumpang tersebut memiliki keterbatasan, agar petugas yang lain dapat membantu mengarahkan penumpang berkebutuhan khusus (kursi roda) tersebut. Untuk penumpang tunanetra jika berpergian sendiri hendaknya dicheck-inkan oleh kerabat terlebih dahulu agar penumpang hanya melapor saja nantinya pada saat di bandadra. Tetapi banyak penumpang yang tidak sesuai aturan sehingga menyebabkan kendala bagi petugas passasi. Hal ini disebabkan karena penumpang tersebut kurang mengetahui informasi-informasi yang ada di bandara, seperti jika penumpang tidak mengetahui gate mana yang akan digunakan untuk memasuki pesawat udara.

Data pembahasan ini diperoleh data melalui observasi serta didukung dengan hasil wawancara yang peneliti lakukan dengan petugas Check-In Counter Maskapai Citilink Bandara Adisutjipto yang menyatakan kendala dalam menangani penumpang disabilitas, yaitu:

a. Penumpang melakukan perjalanan sendiri

Penumpang disabilitas yang melakukan perjalanan sendiri tanpa ada kerabat atau saudara yang menemani, menjadikan sulit dalam melayaninya terutama apabila penumpang tersebut memiliki keterbatasan atau penumpang autis.

b. Penumpang tidak melaporkan kondisi disabilitas kepada petugas

Penumpang disabilitas harus melaporkan sendiri kepada petugas check-in counter agar petugas yang lain dapat membantu mengarahkan penumpang berkebutuhan khusus tersebut sampai ke pintu. Ketika penumpang berkebutuhan khusus ini tidak melapor (self chek-in/check-in web), sehingga menyebabkan penumpang bisa memasuki ruang tunggu (boarding gate) tanpa ada pengawasan dari petugas pasasi, dapat mengganggu ground time boarding yang seharusnya penumpang berkebutuhan khusus (penumpang priority) memasuki pintu pesawat terlebih dahulu, akhinya dengan terpaksa memasukkan penumpang pada saat terakhir karena akibat penumpang disabilitas tidak melapor.

Untuk penumpang tunanetra jika tidak melapor dan berpergian sendiri dapat mengganggu ground time bording karena penumpang tersebut kurang mengetahui informasi-informasi yang ada di bandara, misalnya penumpang tidak mengetahui gate mana yang akan digunakan untuk memasuki pesawat udara. Untuk penumpang 
tunarungu biasanya terkendala bahwa penumpang tidak mengetahui informasi atau aba-aba saat akan memasuki pesawat udara sehingga bisa mengganggu ground time boarding.

3. Cara menangani kendala- kendala dalam melayani penumpang disabilitas pada Maskapai Citilink Bandara Adisutjipto

Petugas check-in akan menangani penumpang dengan sebaik mungkin, sehingga hendaknya penumpang wajib melapor jika mempunyai riwayat sakit/penumpang disabilitas agar mempermudah dan mempercepat proses penanganannya. Penumpang yang membutuhkan kursi roda dapat langsung melapor kepada petugas dan meminta pertolongan untuk diantar sampai ke pesawat.

Data penelitian ini diperoleh dengan cara observasi serta didukung dengan hasil wawancara yang peneliti lakukan staff check-in counter Maskapai Citilink Bandara Adisutjipto, yang menyatakan bahwa dalam hal penanganan penumpang disabilitas untuk penumpang kursi roda, petugas pasasi akan menawarkan bantuan yaitu membantu penumpang dari check-in sampai ke pesawat menggunkan kursi roda yang memang telah disiapkan oleh setiap airlines (jika penumpang bepergian sendirian) dan penumpang akan ditemani sampai naik ke pesawat.

Untuk penumpang tunanetra, harus melapor ke petugas pasasi agar petugas dapat membantu penumpang tersebut serta menemani sampai naik pesawat. Jika penumpang masuk sendirian ke dalam maka tidak akan mengetahui gate yang mana untuk keberangkatan tiketnya, sehingga diperlukan asisten atau petugas maskapai yang bersangkutan untuk membantu penumpang tersebut.

Untuk penumpang tunarungu harus ada petugas yang mengawasi karena penumpang tunarungu tidak mengetahui informasi atau arahan saat memasuki pesawat karena keterbatasan pendengaran yang dimilikinya. Petugas pasasi harus membantu penumpang tersebut dengan cara menulis di kertas bahwa pesawatnya akan segera berangkat dan dipersilahkan memasuki pesawat.

Untuk penumpang autis harus ada keluarga yang mendampinginya untuk mencegah hal-hal yang tidak diinginkan, karena untuk penumpang autis ini biasanya hanya keluarga atau kerabat dekat yang mampu mengatasinya jika penyakitnya kambuh.

\section{KESIMPULAN DAN SARAN}

1. Kesimpulan

Berdasarkan hasil pembahasan di atas maka dapat ditarik kesimpulan sebagai berikut:

a. Penanganan penumpang disabilitas pada Maskapai Citilink di Bandar Udara Internasional Adisujipto Yogyakarta, petugas check-in akan memeriksa setiap identitas penumpang, hal ini dilakukan agar mempermudah petugas mengetahui kondisi setiap penumpang. Di counter check-in, setiap penumpang yang memiliki riwayat sakit wajib melapor agar mendapatkan pelayanan yang baik selama penerbangan, seperti halnya jika penumpang membutuhkan kursi roda, penumpang ingin didampingi sampai naik pesawat maka petugas akan memberikan pelayanan yang baik agar penumpang merasa tidak khawatir karena berangkat sendiri tanpa ada kerabat/keluarga. Agar proses penanganan penumpang berlangsung dengan cepat diharapkan penumpang tiba lebih awal di bandara, membawa dokumen medis, membawa obat-obatan dan membeli asuransi pejalanan.

b. Kendala-kendala dalam melayani penumpang disabilitas pada Maskapai Citilink di Bandar Udara Internasional Adisujipto Yogyakarta sebagai berikut

1) Penumpang melakukan perjalanan sendiri tanpa ada kerabat yang menemani. 
2) Penumpang harus melapor sendiri ke petugas check-in counter .

c. Penumpang disabilitas tidak melapor ke petugas (self check-in/check-in web)

d. Cara menangani kendala-kendala dalam melayani penumpang disabilitas pada Maskapai Citilink di Bandar Udara Internasional Adisujipto Yogyakarta yaitu sebagai berikut

1) Jika penumpang (kursi roda, tunarungu,tunanetra) melakukan perjalanan sendiri maka petugas akan menawarkan bantuan baik berupa kursi roda atau pendamping selama check-in hingga sampai ke dalam pesawat. Khusus penumpang autis harus ada kerabat yang menemani, tidak dapat berpergian sendiri.

2) Penumpang yang berpergian sendiri, hendaknya reservasi tiket di maskapai secara langsung. Hal ini akan lebih memudahkan penumpang disabilitas karena bisa di check-in kan langsung dan bisa diantar oleh pihak maskapai tersebut tanpa harus mengantri di counter check-in.

3) Ketika penumpang disabilitas tidak melapor ke counter check-in pada saat memasuki ruang tunggu, pada saat boarding, special passanger akan dibantu naik pesawat oleh petugas pasasi dimana penumpang tersebut naik pesawat setelah penumpang lain masuk ke pesawat (seharusnya penumpang disabilitas naik lebih dahulu).

2. Saran

a. PT. Gapura Angkasa Yogyakarta selaku naungan ground handling Citilink hendaknya mempersiapkan petugas tersendiri untuk khusus pengantar kursi roda, penerjemah untuk penumpang tunarungu,dan asisten (pendamping) bagi penumpang yang akan bepergian sendiri sampai naik ke pesawat seperti tunarungu, agar tidak menyulitkan petugas counter check-in pada saat antrian penumpang untuk check-in.

b. Maskapi Citilink hendaknya secara periodik memberikan pelatihan penanganan penumpang disabilitas agar dapat memberikan pelayanan prima kepada penumpang disabilitas.

\section{DAFTAR PUSTAKA}

Arikunto, S. (2013). Prosedur Penelitian: Suatu Pendekatan Praktik. Jakarta: Rineka Cipta.

Direktorat Jenderal Perhubungan Udara, 2017. Pengertian, Peran, dan Fungsi Bandar Udara. Jakarta: Direktorat Jenderal Perhubungan Udara . Tersedia: http://hubud.dephub.go.id/website/bandara.php.

Ghony, M. Djunaidi dan Fauzan Almanshur, 2014. Metodologi Penelitian Kualitatif. Yogyakarta: Ar Ruzz Media.

Handoyo, Singgih, 2011. Aviapedia: Ensiklopedia Umum Penerbangan, Volume 1. Jakarta: PT. Kompas Media Nusantara.

Herdiansah Lisa, 2012. Bandara. http://lisaherdiana.blogspot.com

Kurniawan, Hari, 2015. Aksebilitas Peradilan Bagi Penyandang Disabilitas, Yogyakarta PUSHAM UII

Nursyamsi, Fajri, 2005. Kerangka Hukum Disabilitas di Indonesia: Menuju Indonesia Ramah Disabilitas. Jakarta. Pusat Studi Hukum dan Kebijakan Indonesia (PSHK).

Peraturan Mentri Perhubungan Nomor PM 31 Tahun 2013 Tentang Program Keamanan Penerbangan Nassional 
Peraturan Mentri Perhubungan No. 185 Tahun 2015 Tentang Standard Pelayanan Penumpang Kelas Ekonomi Angkutan Udara Niaga Berjadwal Dalam Negeri

Prastowo, Andi, 2014. Metode Penelitian Kualitatif dalam Perspektif Rancangan Penelitian. Yogyakarta: Ar Ruzz Media.

Purhantara, Wahyu, 2010. Metode Penelitian Kualitatif untuk Bisnis. Yogyakarta: Graha Ilmu.

Siswanto, 2012. Pengantar Manajemen. Jakarta: PT. Bumi Aksara.

Soekanto, Soerjono, 2012. Sosiologi Suatu Pengantar. Jakarta: Rajawali Pers.

Sugiyono, 2012. Memahami Penelitian kualitatif. Bandung: ALFABETA. , 2015. Metode Penelitian Kombinasi (Mix Methods). Bandung: Alfabeta. 2017. Metode Penelitian Kuantitatif, Kualitatif, dan R\&D. Bandung: Alfabeta, CV.

Thoha, Miftah, 2012. Kepemimpinan Dalam Manajemen. Jakarta: PT. Raja Grafindo Persada.

Undang-Undang Republik Indonesia No. 1 tahun 2009 tentang penerbangan telah menengaskan secara detail bagaimana prosedur pelakuan khusus kepada penyandang disabilitas.

Undang-Undang No. 2 Tahun 2009 Tentang Penerbangan. 